\title{
RUCH NATURALNY LUDNOŚCI A OBCIĄŻENIE DEMOGRAFICZNO-EKONOMICZNE W PAŃSTWACH UNII EUROPEJSKIEJ (ANALIZA PORÓWNAWCZA)
}

\section{WSTEP}

W krajach należących do Unii Europejskiej obserwuje się niekorzystne tendencje zmian struktur demograficznych powodujące nasilanie zjawiska starzenia się społeczeństw krajów członkowskich: 1 stycznia 2010 r. ponad 87 milionów osób było w wieku 65 lat i więcej, co stanowiło ponad $17 \%$ ogółu ludności Unii Europejskiej. Jednocześnie wraz z rozwojem technologicznym, poprawą warunków życia, wzrastającą zamożnością społeczeństw i rozwojem medycyny obserwujemy ciagły wzrost wartości przeciętnego trwania życia, co w prosty sposób oznacza, że żyjemy coraz dłużej. Te czynniki, wraz z obserwowanym w krajach Unii Europejskiej spadkiem dzietności, oznaczającym zmniejszanie się liczby urodzeń, powoduja dalsze nasilenie procesu starzenia się społeczeństw. Tendencje te obserwuje się od 30-40 lat i przewiduje, że będa się one utrzymywać przez co najmniej kolejnych 50 lat.

Wzrost udziału w ogólnej liczbie ludności osób w wieku 65 lat i więcej, co dziś uważa się za wiek poprodukcyjny, stawia wyzwania przed organami rządzącymi państwami, powoduje konieczność dostosowania polityki fiskalnej, socjalnej, zdrowotnej, a także nowego spojrzenia na uwarunkowania i ograniczenia budżetu państwa, rynku pracy i systemu ubezpieczeniowego. Jakkolwiek zjawisko starzenia się społeczeństwa wywołuje skutki ekonomiczne zarówno dla gospodarek państwowych, jak i gospodarstw domowych jego przyczyny mają podłoże demograficzne.

Celem niniejszego artykułu jest przedstawienie relacji, jakie zachodza pomiędzy miernikami ruchu naturalnego ludności, na który składają się urodzenia i zgony, a demograficznymi wskaźnikami starzenia się społeczeństwa, wśród których zostały wzięte pod uwagę mediana wieku oraz współczynniki obciążenia demograficznego. Analiza została przeprowadzona na podstawie danych dotyczacych 27 krajów należących do Unii Europejskiej. Dane dotyczą 2010 r., a ich źródłem jest baza danych Eurostatu.

\section{STARZENIE SIE SPOŁECZEŃSTW}

Istnieje wiele wskaźników opisujących proces starzenia się społeczeństwa. Do celów niniejszej analizy zostały wybrane: mediana wieku ludności oraz współczynniki obciążenia demograficznego. 
Mediana wieku jest wartością przeciętną wieku ludności rozumianą jako wartość dzieląca społeczeństwo na dwie równoliczne grupy: osób młodszych oraz osób starszych od wartości mediany.

\section{Wykres 1}

Mediana wieku ludności w krajach Unii Europejskiej w 2010 r.

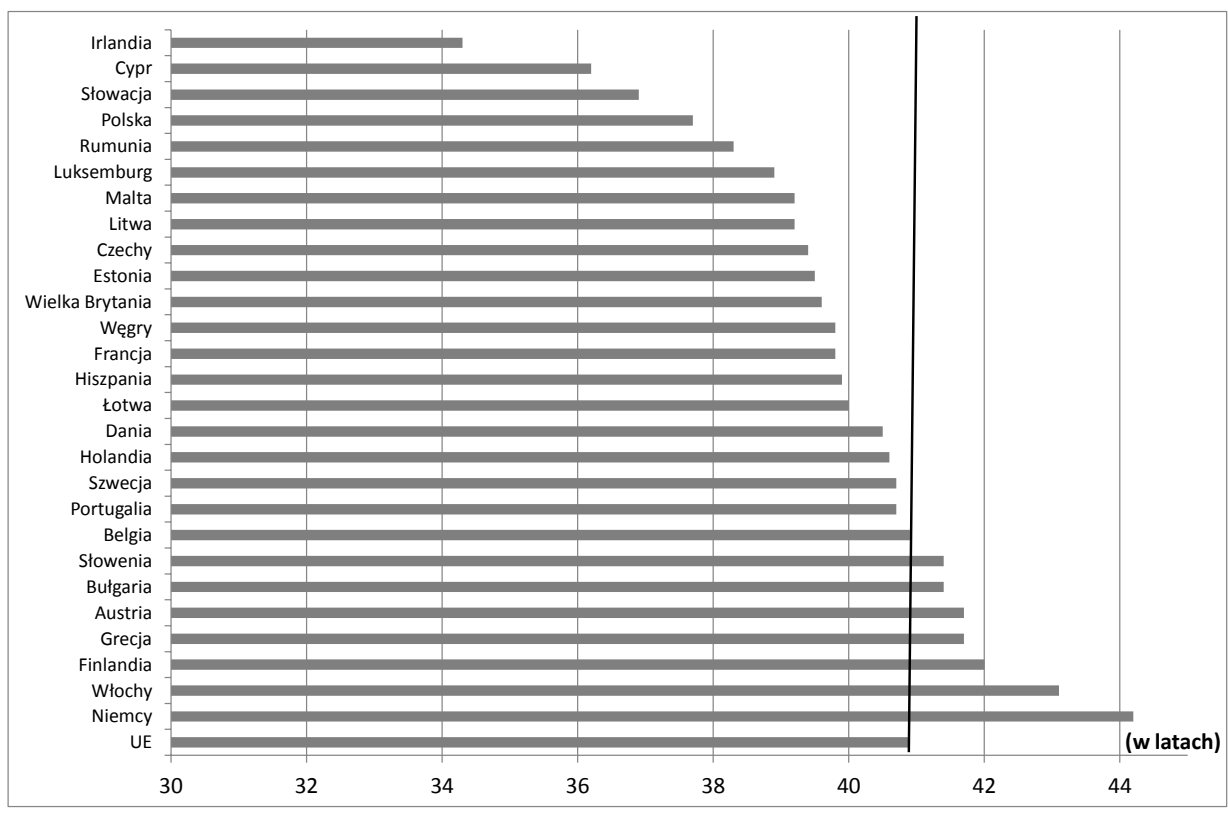

Źródło: opracowanie własne na podstawie danych bazy Eurostat, http://epp.eurostat.ec.europa.eu.

Porównując wartość mediany wieku w krajach Unii Europejskiej, możemy wnioskować, w którym kraju społeczeństwo jest młodsze, a w którym starsze. Dane dotyczące mediany wieku w dniu 1 stycznia 2010 r. (wykres 1) wskazuja, że do najstarszych wiekowo społeczeństw należą Niemcy (przeciętnie 44,2 roku), Włochy (43,1 roku), Finlandia (42 lata), Grecja i Austria (po 41,7 roku), Bułgaria i Słowenia (po 41,4 roku). W krajach tych mediana wieku przekracza wartość średnią w Unii Europejskiej, wynosząca 40,9 roku. W pozostałych 20 krajach UE wartość mediany jest nie wyższa od 40,9 roku, a najniższym wiekiem środkowym wyróżnia się Irlandia (34,3 roku). Polska (z wynikiem 37,7 roku) zajmuje 4 miejsce w Unii Europejskiej, tym samym zalicza się do społeczeństw stosunkowo młodych w tym rejonie.

Na wykresie 2 zostały przedstawione współczynniki obciążenia demograficznego w krajach Unii Europejskiej oszacowane na podstawie informacji o liczbie ludności 1 stycznia $2010 \mathrm{r}$.

Współczynnik obciążenia ludźmi młodymi (w wieku poniżej 15 lat) mówi nam, ile osób w wieku przedprodukcyjnym przypada na 100 osób w wieku produkcyjnym. Mimo że ludzie młodzi stanowią obciążenie ekonomiczne dla 


\section{Wykres 2}

Współczynniki obciążenia demograficznego w krajach Unii Europejskiej w 2010 r.

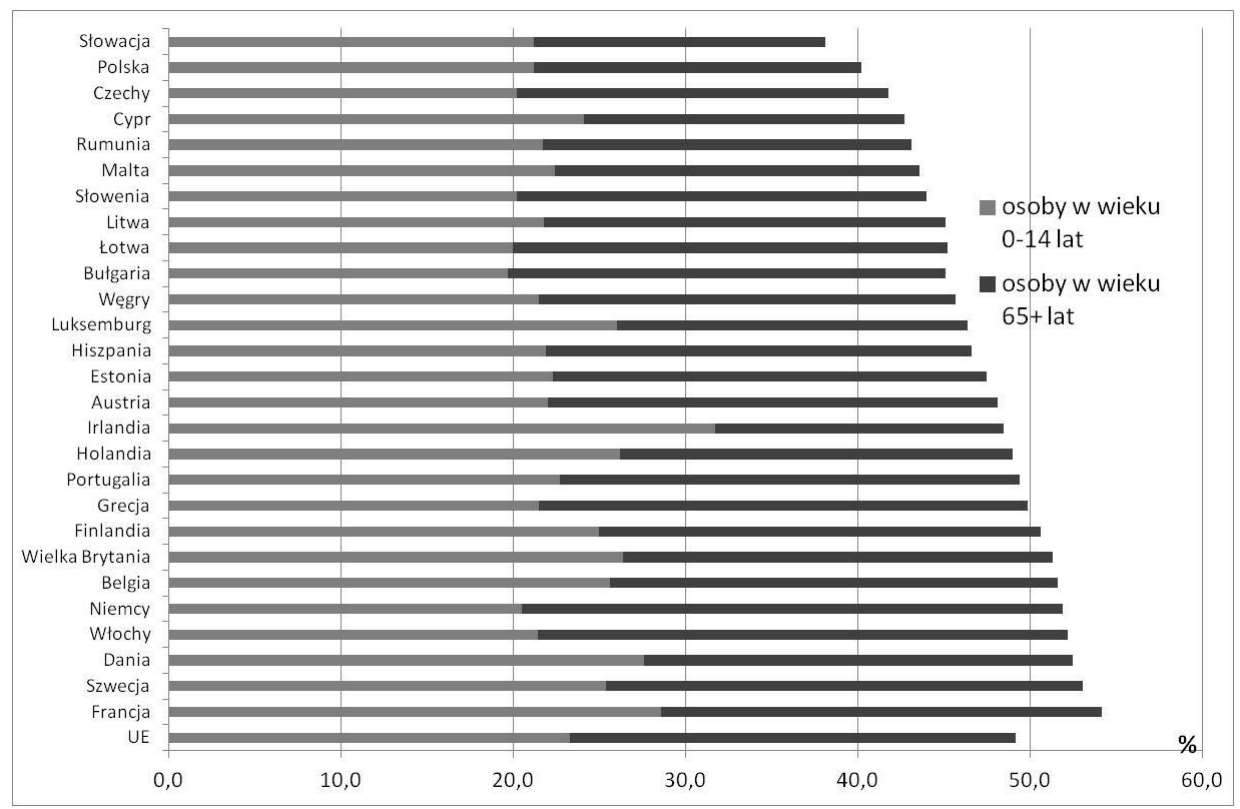

Źródło: opracowanie własne na podstawie danych bazy Eurostat, http://epp.eurostat.ec.europa.eu.

ludzi w wieku produkcyjnym, jest to obciążenie rozumiane pozytywnie, gdyż pozwala nam w optymistyczny sposób przewidywać przyszłość oraz stanowi siłę przeciwstawną tendencji starzenia się społeczeństw - ludzie w wieku przedprodukcyjnym w przyszłości będą stanowić siłę produkcyjną społeczeństwa. Według danych z 1 stycznia 2010 r. średnie obciążenie demograficzne ludźmi młodymi w Unii Europejskiej wynosiło 23,3\%, co oznacza, że średnio trochę ponad cztery osoby w wieku produkcyjnym ,,utrzymywały” jedną osobę w wieku poniżej 15 lat. Najwyższa wartość tego wskaźnika wystąpiła w Irlandii - 31,7, a także we Francji - 28,6, natomiast wskaźnik najniższą wartość przyjął w Bułgarii - 19,7, na Łotwie - 20 oraz w Czechach i w Słowenii - po 20,2. Polska ze wskaźnikiem obciążenia ludźmi młodymi wynoszącym 21,2 zajmuje wraz ze Słowacją 23 miejsce na 27 krajów należących do Unii Europejskiej (w kolejności od najwyższej wartości współczynnika).

Współczynnik obciążenia ludźmi starszymi (w wieku 65 lat i więcej) oznacza liczbę osób w wieku poprodukcyjnym przypadająca na 100 osób w wieku produkcyjnym. Jest to negatywny aspekt obciążenia demograficznego, a wysoka wartość współczynnika świadczy o zaawansowanym etapie starzenia się społeczeństwa i stawia przed polityką społeczną państwa, jego systemem zdrowotnym, emerytalnym i socjalnym, wyzwania, którym niełatwo jest sprostać. W Unii Europejskiej średnia wartość współczynnika obciążenia ludźmi starszymi w 2010 r. wynosiła 25,9, co oznacza, że na każdą osobę 
$\mathrm{w}$ wieku poprodukcyjnym przypadaja średnio niecałe 4 osoby w wieku produkcyjnym. Najwyższy poziom obciążenia osobami starszymi wystąpił w Niemczech $(31,4)$, we Włoszech $(30,8)$ i w Grecji $(28,4)$, a najniższy w Irlandii $(16,8)$ i na Słowacji $(16,9)$. Polska pod względem obciążenia ludźmi starszymi znajduje się na czwartym miejscu wśród krajów Unii Europejskiej (współczynnik wynosi 19), co oznacza, że jesteśmy wciąż społeczeństwem relatywnie młodym.

Obciążenie ludźmi młodymi oraz obciążenie ludźmi starszymi w sumie składają się na ogólne obciążenie demograficzne, a więc obciążenie ludności w wieku produkcyjnym ludnością w wieku nieprodukcyjnym. W Unii Europejskiej jedną osobę $\mathrm{w}$ wieku nieprodukcyjnym ,utrzymują" średnio trochę ponad dwie osoby w wieku produkcyjnym. Najwyższą wartość w 2010 r. współczynnik obciążenia demograficznego osiąnął we Francji (54,2). Poza Francja jeszcze w siedmiu innych krajach: Szwecji, Danii, Niemczech, Belgii, Wielkiej Brytanii, Finlandii i we Włoszech, jego wartość przekroczyła próg 50\%, co oznacza, że $\mathrm{w}$ tych krajach na każdą osobę $\mathrm{w}$ wieku nieprodukcyjnym przypadają mniej niż dwie osoby w wieku produkcyjnym. Najniższe obciążenie demograficzne wystąpiło na Słowacji $(38,1)$ oraz w Polsce $(40,2)$, gdzie średnio około 2,5 osoby w wieku produkcyjnym ,,pracuja” na jedną osobę w wieku nieprodukcyjnym.

\section{RUCH NATURALNY LUDNOŚCI}

Urodzenia są elementem ruchu naturalnego ludności i wraz ze zgonami kształtują liczbę ludności na danym terenie w określonym czasie. Miernikiem natężenia urodzeń, służącym do porównań międzynarodowych oraz do śledzenia zmian tego zjawiska, jest ogólny współczynnik urodzeń. Jest on równy liczbie urodzeń w ciągu roku, przypadających na średnią liczbę ludności w tym samym roku.

W 2010 r. w krajach Unii Europejskiej na każde 1000 ludności rodziło się średnio 10,7 dziecka (wykres 3). Ogólny współczynnik urodzeń najwyższą wartość przyjął w Irlandii, która pod tym względem znacznie odbiega od reszty członków Unii Europejskiej. W kraju tym w 2010 r. na każde 1000 ludności przypadało średnio 16,5 urodzeń. Wysokie wartości wskaźnik ten przyjął również w Wielkiej Brytanii (13), Francji $(12,9)$, na Cyprze $(12,4)$ i w Szwecji $(12,3)$. Najmniej urodzeń na 1000 ludności wystapiło w Niemczech - zaledwie 8,3, czyli prawie o połowę mniej niż w Irlandii. W Polsce ogólny współczynnik urodzeń w 2010 r. wyniósł 10,8, podobnie jak na Litwie i w Słowenii, co powoduje, że znajdujemy się wśród krajów Unii Europejskiej w połowie stawki.

Zgony, z demograficznego punktu widzenia, powoduja ubywanie populacji i stanowią ujemny składnik przyrostu naturalnego. Natężenie zgonów w fazie drugiego przejścia demograficznego, w której znajduja się kraje europejskie, jest niskie. Jego rozkład względem wieku przyjmuje kształt zbliżony do litery „U” ze skrajną asymetrią lewostronną - natężenie zgonów jest niskie poniżej 1 roku życia i nieznacznie spada wraz z wiekiem, a następnie po osiągnięciu minimum 


\section{Wykres 3}

Ogólny współczynnik urodzeń w krajach Unii Europejskiej w 2010 r.

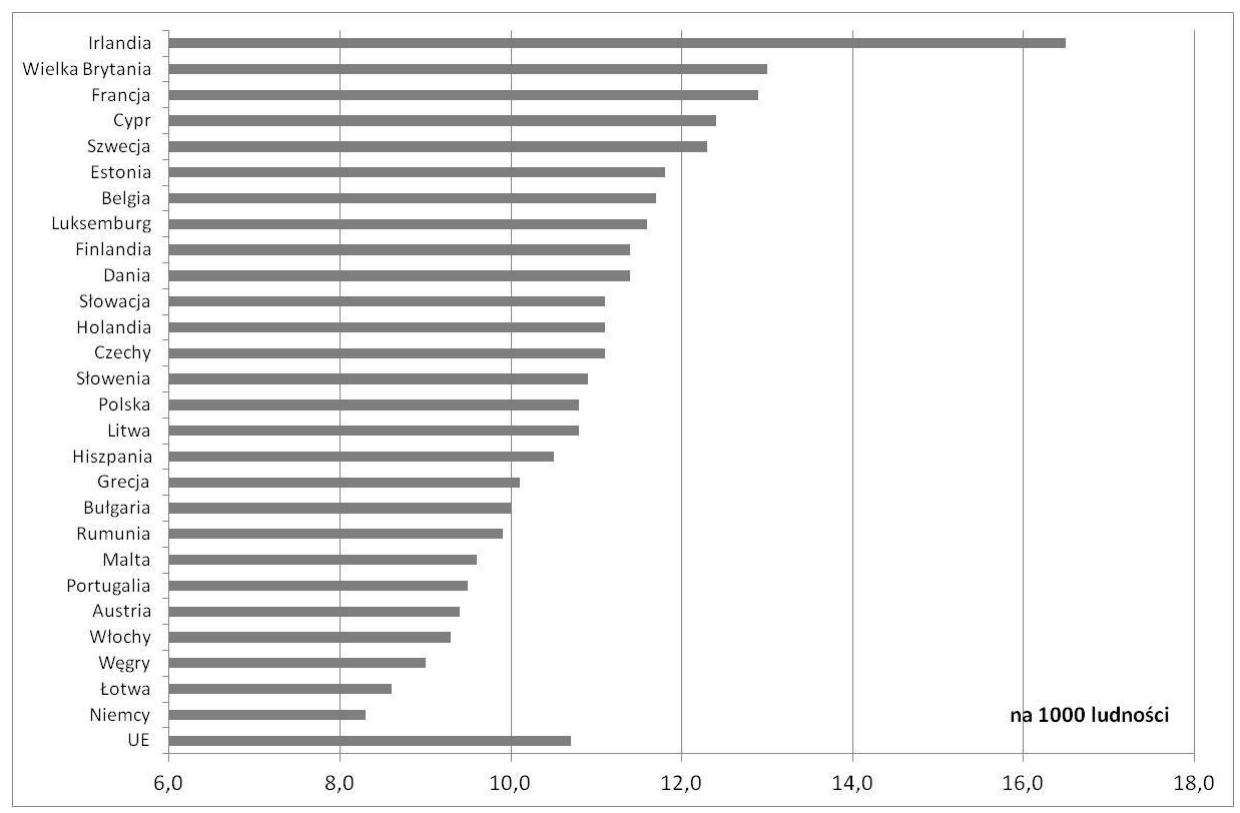

Źródło: opracowanie własne na podstawie danych bazy Eurostat, http://epp.eurostat.ec.europa.eu.

w wieku lat kilkunastu-dwudziestu, nieprzerwanie wzrasta. W związku z tym zgony powodują spadek liczby ludności przede wszystkim w starszych rocznikach. Miernikiem natężenia zgonów jest ogólny współczynnik zgonów, oznaczający stosunek liczby zgonów zaszłych w ciagu roku do średniej liczby ludności w tym samym roku.

W Unii Europejskiej w 2010 r. odnotowano średnio 9,7 zgonu na 1000 mieszkańców (wykres 4). Współczynnik zgonów najwyższą wartość osiągnął w Bułgarii $(14,6)$, poza tym wysokie natężenie zgonów odnotowano również na Łotwie (13,4), Węgrzech (13), Litwie $(12,8)$, w Rumunii $(12,1)$ i Estonii $(11,8)$. Polska charakteryzuje się również wysoką wartością współczynnika zgonów, zbliżoną do średniej dla Unii Europejskiej, równą 9,9. Pod względem natężenia zgonów znajdujemy się w Unii Europejskiej na 18 miejscu. Najniższe natężenie zgonów w 2010 r. odnotowano w Irlandii (6,1), na Cyprze (6,7), Malcie $(7,2)$ i w Luksemburgu $(7,4)$.

Urodzenia i zgony są elementami ruchu naturalnego ludności. Dopiero te dwa zjawiska rozpatrywane łącznie mogą dać nam obraz zmian liczebności populacji i jej struktury względem wieku.

Urodzenia wpływają na liczebność populacji w najniższym przedziale wieku (dół piramidy wieku ludności), natomiast zgony kształtują liczebność populacji przede wszystkim w późniejszych przedziałach wieku (góra piramidy wieku 


\section{Wykres 4}

Ogólny współczynnik zgonów w krajach Unii Europejskiej w 2010 r.

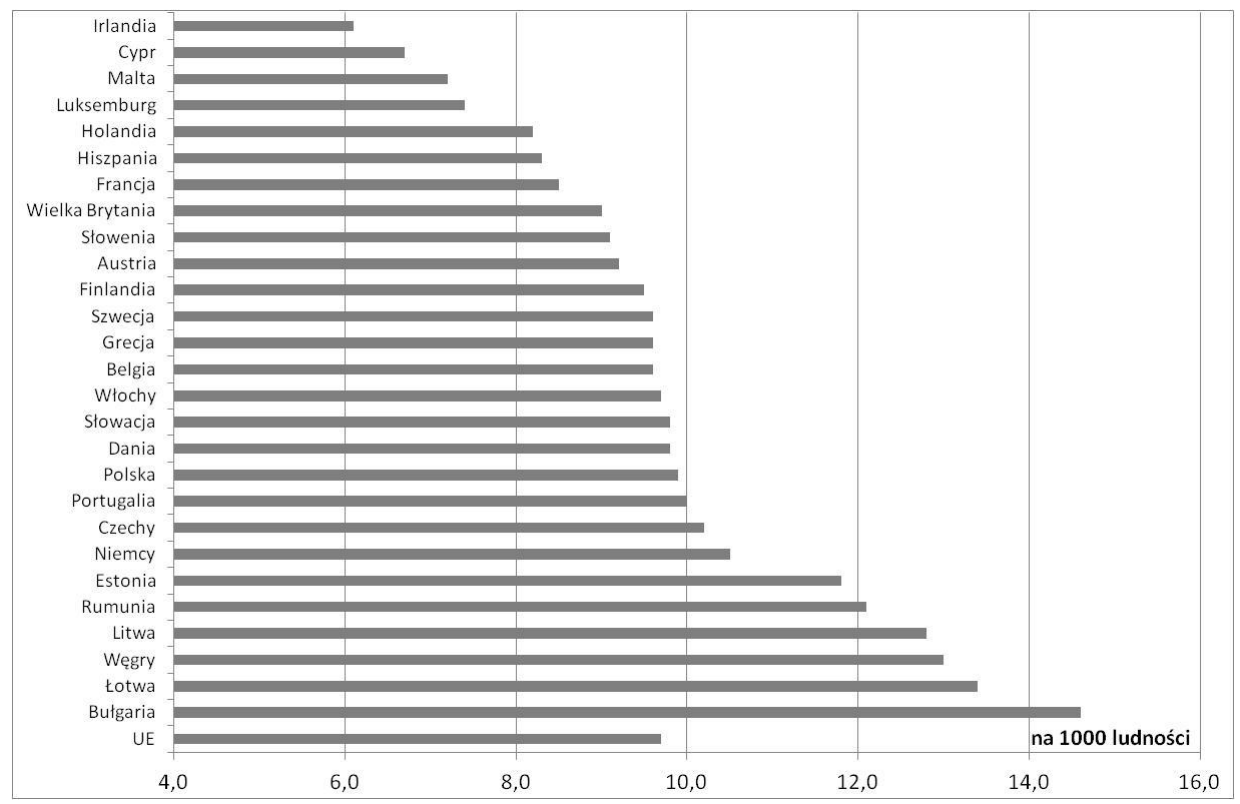

Źródło: opracowanie własne na podstawie danych bazy Eurostat, http://epp.eurostat.ec.europa.eu.

ludności). Dlatego relacja między liczbą urodzeń a zgonów zmienia strukturę ludności względem wieku.

Różnica pomiędzy liczbą urodzeń a liczbą zgonów jest nazywana przyrostem naturalnym. W populacjach, w których w danym roku liczba urodzeń jest wyższa od liczby zgonów w tym samym roku, występuje dodatni przyrost naturalny, natomiast w populacjach o wyższej liczbie zgonów od liczby urodzeń, mówimy o ujemnym przyroście naturalnym.

Współczynnik przyrostu naturalnego to przyrost naturalny przypadający na 1000 ludności. W 2010 r. wyniósł on dla Unii Europejskiej 1 (wykres 5). Oznacza to, że na każde 1000 mieszkańców Unii nadwyżka liczby urodzeń nad liczbą zgonów wynosiła 1. Przyrost naturalny był więc dodatni, choć miał bardzo niskie natężenie.

Osiem krajów wchodzących w skład Unii Europejskiej zanotowało w 2010 r. ujemny przyrost naturalny. Były to przede wszystkim Bułgaria, Łotwa i Węgry, ze współczynnikiem przyrostu naturalnego poniżej -4 oraz Litwa, Niemcy i Rumunia (współczynnik poniżej -2). Niewielki ujemny przyrost naturalny został również odnotowany w Portugalii i we Włoszech (współczynnik równy -0,4).

Dodatni przyrost naturalny największe natężenie przybrał w Irlandii, gdzie na każde 1000 mieszkańców nadwyżka liczby urodzeń nad liczbą zgonów 


\section{Wykres 5}

Współczynnik przyrostu naturalnego w krajach Unii Europejskiej w 2010 r.

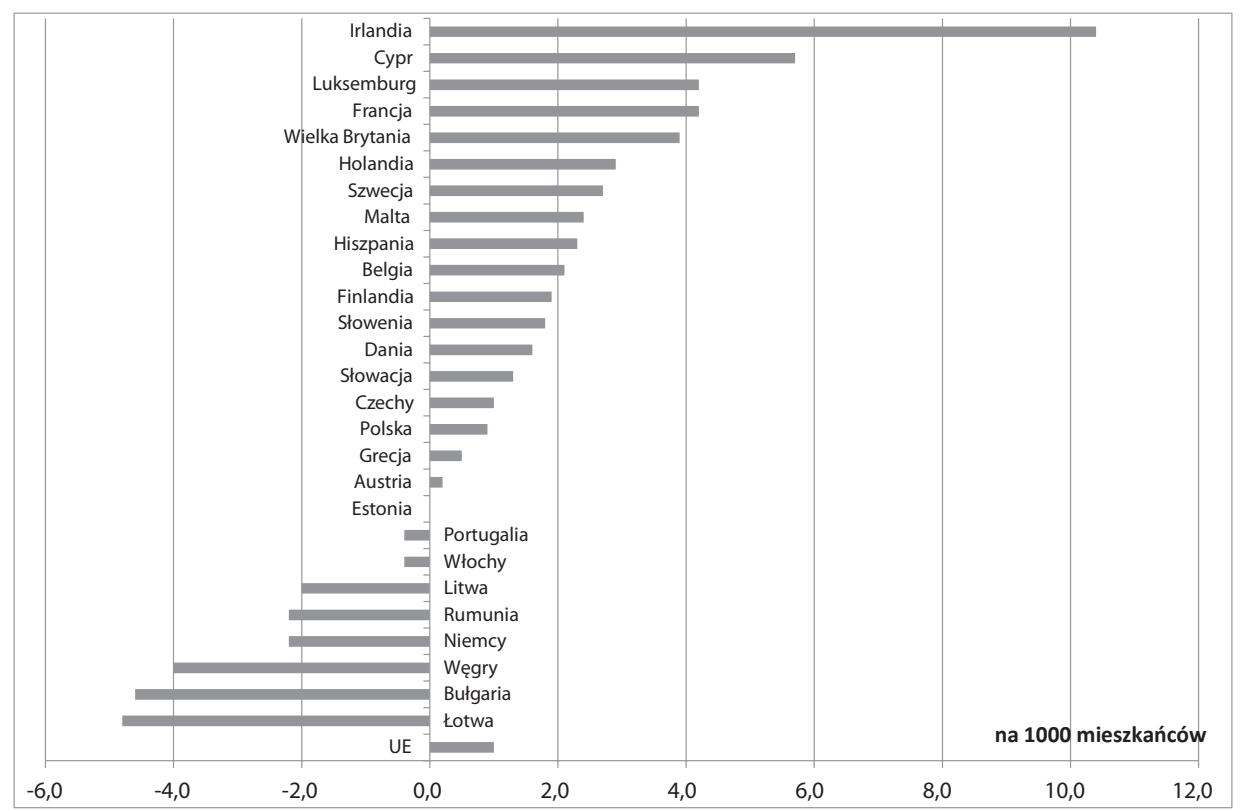

Źródło: opracowanie własne na podstawie danych bazy Eurostat, http://epp.eurostat.ec.europa.eu.

wynosiła 10,4. Już nie tak wysoką, lecz również odbiegającą od innych krajów wartość współczynnika przyrostu naturalnego odnotowano na Cyprze $(5,7)$. Wyraźnie dodatni przyrost naturalny poza tym wystąpił w Luksemburgu, we Francji (po 4,2) i Wielkiej Brytanii (3,9). W Estonii nie odnotowano przyrostu naturalnego, natomiast w Austrii i Grecji współczynnik przyrostu wyniósł niewiele powyżej 0. Natężenie przyrostu naturalnego w Polsce, a także w Czechach kształtowało się na poziomie średniej dla Unii Europejskiej. Pod względem wartości współczynnika przyrostu naturalnego Polska znajduje się na 16 miejscu w Unii.

Dane statystyczne wskazują, że sytuacja demograficzna Irlandii znacznie odbiega od innych krajów Unii Europejskiej. Przyrost naturalny w Irlandii jest 16 razy silniejszy, niż w całej Unii Europejskiej i o ponad 80\% wyższym natężeniu, niż na drugim pod względem jego wartości Cyprze. Jest to bezpośrednią konsekwencją najniższego natężenia zgonów połączonego z najwyższym natężeniem urodzeń w Irlandii.

Jednak ta relacja pomiędzy natężeniem urodzeń i zgonów nie jest wyjątkowa. Można powiedzieć, że typowe dla krajów Unii Europejskiej jest to, że tam, gdzie mamy do czynienia ze stosunkowo wysokim natężeniem urodzeń, występuje też stosunkowo niskie natężenie zgonów (oprócz Irlandii sytuacja taka wystąpiła w 2010 r. między innymi na Cyprze, we Francji, Wielkiej Brytanii). 
Z kolei większość krajów o niskim natężeniu urodzeń wyróżnia się również stosunkowo wysokim natężeniem zgonów (m.in. Litwa, Węgry, Rumunia, Niemcy). Od tego schematu odstają Austria, Hiszpania i Malta, gdzie natężenie urodzeń i zgonów jest stosunkowo niskie, oraz Estonia, w której składniki ruchu naturalnego mają wysokie natężenie (choć ich efekt znosi się wzajemnie, powodując zerowy przyrost naturalny).

\section{RELACJA POMIECDZY ELEMENTAMI RUCHU NATURALNEGO LUDNOŚCI A WSPÓŁCZYNNIKAMI OBCIĄŻENIA DEMOGRAFICZNEGO}

W celu zbadania relacji, jakie łączą wartości wskaźników starzenia się społeczeństwa z bieżącymi miernikami natężenia ruchu naturalnego ludności, została przeprowadzona analiza korelacji pomiędzy parametrami należącymi do obu grup. Parametrem wykorzystanym do oceny współzależności był współczynnik korelacji rang Spearmana. Wyniki zostały przedstawione w tabeli 1.

\section{Tabela 1}

Współczynniki korelacji rang Spearmana pomiędzy miernikami ruchu naturalnego ludności a wskaźnikami obciążenia demograficznego w 27 krajach Unii Europejskiej w 2010 r.

\begin{tabular}{|c|c|c|c|}
\hline \multirow[b]{2}{*}{$\begin{array}{c}\text { Wskaźniki } \\
\text { obciażzenia } \\
\text { demograficznego }\end{array}$} & \multicolumn{3}{|c|}{ Mierniki ruchu naturalnego ludności } \\
\hline & $\begin{array}{l}\text { Ogólny } \\
\text { współczynnik } \\
\text { urodzeń }\end{array}$ & $\begin{array}{l}\text { Ogólny } \\
\text { współczynnik } \\
\text { zgonów }\end{array}$ & $\begin{array}{c}\text { Współczynnik } \\
\text { przyrostu } \\
\text { naturalnego }\end{array}$ \\
\hline Mediana wieku & $-0,38$ & 0,17 & $-0,32$ \\
\hline $\begin{array}{l}\text { Współczynnik } \\
\text { obciążenia ludnością } \\
\text { w wieku poniżej } \\
14 \text { lat }\end{array}$ & 0,69 & $-0,64$ & 0,74 \\
\hline $\begin{array}{l}\text { Współczynnik } \\
\text { obciążenia ludnością } \\
\text { w wieku } 65 \text { lat } \\
\text { i więcej }\end{array}$ & $-0,31$ & 0,27 & $-0,36$ \\
\hline $\begin{array}{l}\text { Współczynnik } \\
\text { obciążenia } \\
\text { demograficznego }\end{array}$ & 0,19 & $-0,17$ & 0,19 \\
\hline
\end{tabular}

Źródło: obliczenia własne na podstawie danych bazy Eurostat, http://epp.eurostat.ec.europa.eu.

Analiza współzależności pomiędzy natężeniem ruchu naturalnego ludności a wskaźnikami obciążenia demograficznego wykazała, że w krajach charakteryzujących się w 2010 r. wysokim natężeniem urodzeń występuje stosunkowo wysokie obciążenie ludności w wieku produkcyjnym ludnością w wieku przedprodukcyjnym (współczynnik korelacji równy 0,69 ). 


\section{Wykres 6}

Zależność między współczynnikiem urodzeń a współczynnikiem obciążenia ludźmi młodymi w 27 krajach Unii Europejskiej w 2010 r.

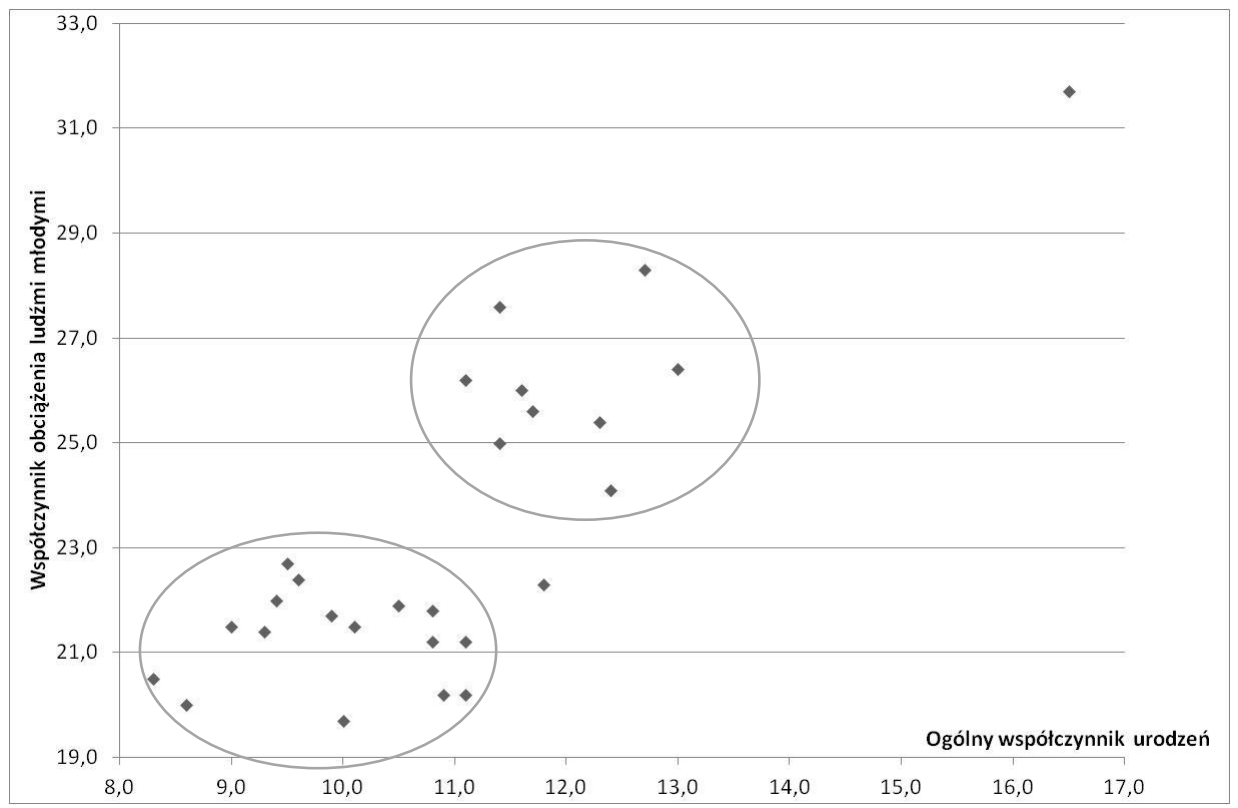

Źródło: opracowanie własne na podstawie danych bazy Eurostat, http://epp.eurostat.ec.europa.eu.

Na podstawie wartości współczynnika urodzeń i współczynnika obciążenia osobami w wieku przedprodukcyjnym możemy wyodrębnić grupy krajów należących do Unii Europejskiej (wykres 6). W jednej grupie znajdą się kraje charakteryzujące się w $2010 \mathrm{r}$. wysokim natężeniem urodzeń i wysokim obciążeniem ludźmi młodymi. Sa to takie kraje, jak: Belgia, Cypr, Dania, Finlandia, Francja, Holandia, Luksemburg, Szwecja i Wielka Brytania. Wśród krajów Unii Europejskiej wyraźnie wyróżnia się Irlandia z bardzo wysokim ogólnym współczynnikiem urodzeń, wynoszącym 16,5 i jednocześnie bardzo wysokim obciążeniem ludźmi młodymi - na poziomie 31,7. W Estonii omawiane mierniki są na średnim poziomie wynoszącym 11,8 (współczynnik urodzeń) i 22,3 (współczynnik obciążenia). Pozostałe 16 krajów znajdzie się w grupie o niskim natężeniu urodzeń i małym obciążeniu ludnością w wieku przedprodukcyjnym.

Również można zaobserwować współwystępowanie wysokich wartości współczynnika obciążenia ludźmi w wieku przedprodukcyjnym wraz z niskim natężeniem zgonów oraz niskich wartości współczynnika obciążenia wraz z wysokim natężeniem zgonów (współczynnik korelacji -0,64).

Na podstawie obserwacji diagramu korelacyjnego przedstawiającego zależność pomiędzy tymi dwiema cechami (wykres 7) można wyodrębnić grupę krajów charakteryzujących się wysokim poziomem współczynnika zgonów. Do 


\section{Wykres 7}

Zależność między współczynnikiem zgonów a współczynnikiem obciążenia ludźmi młodymi w 27 krajach Unii Europejskiej w 2010 r.

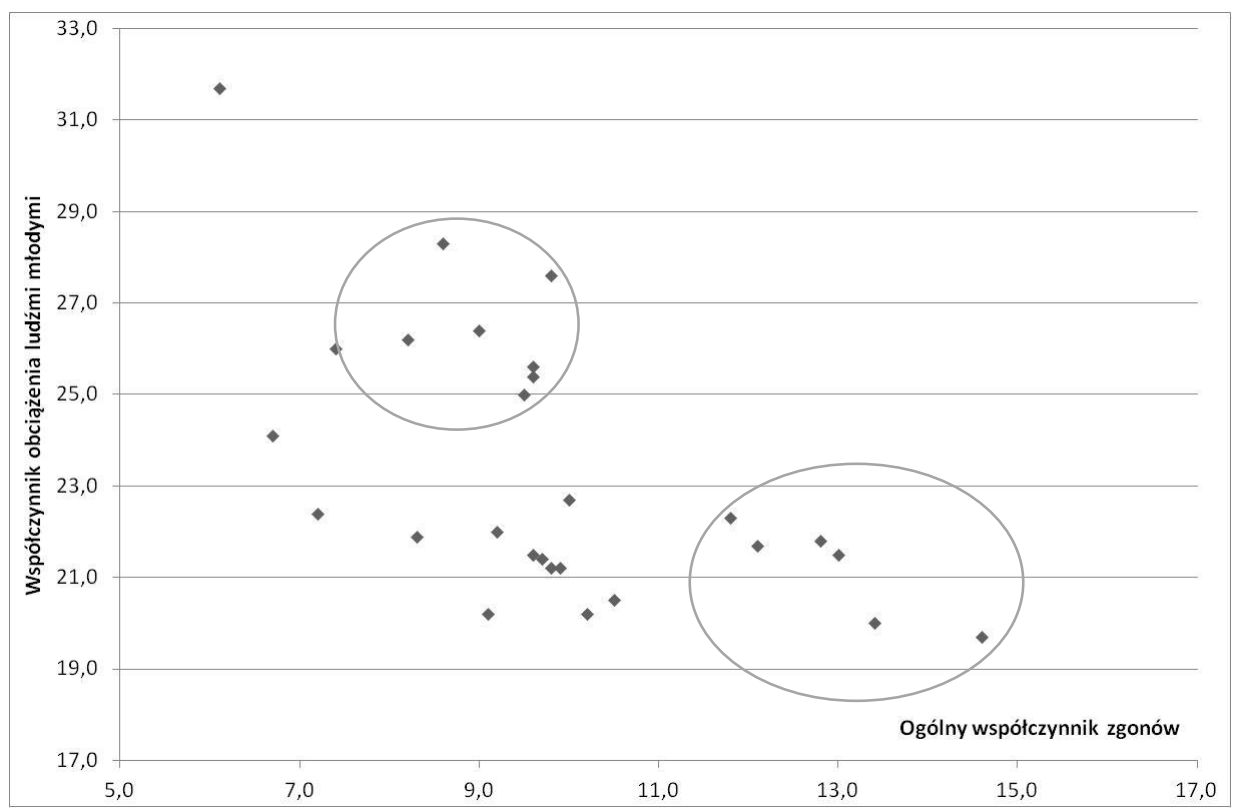

Źródło: opracowanie własne na podstawie danych bazy Eurostat, http://epp.eurostat.ec.europa.eu.

grupy tej należą: Bułgaria, Estonia, Litwa, Łotwa, Rumunia i Węgry. W tych krajach obciążenie demograficzne ludnością $\mathrm{w}$ wieku przedprodukcyjnym jest niskie. Z kolei w Belgii, Danii, Finlandii, Francji, Holandii, Luksemburgu, Szwecji i Wielkiej Brytanii występuje niskie natężenie zgonów oraz wysokie obciążenie ludnością w wieku 14 lat i mniej. Taka sama sytuacja występuje w Irlandii, gdzie wartości omawianych mierników są wyraźnie odstające. Pozostałe kraje charakteryzuja się niskim poziomem współczynnika zgonów i jednocześnie stosunkowo niskimi wartościami obciążenia ludnością w wieku przedprodukcyjnym.

Wyraźną zależnością o kierunku dodatnim charakteryzuja się również wartości współczynnika przyrostu naturalnego i współczynnika obciążenia ludnością w wieku przedprodukcyjnym (współczynnik korelacji wynosi 0,74). W krajach, w których liczba urodzeń w ciagu roku znacznie przewyższa liczbę zgonów, jednocześnie występuje wysoka liczba ludności w wieku 14 lat i mniej przypadająca na 100 osób w wieku 15-64 lata. Do takich krajów zalicza się przede wszystkim Irlandia o znacznie odbiegających od pozostałych krajów wartościach omawianych współczynników, a także: Belgia, Cypr, Dania, Finlandia, Francja, Holandia, Luksemburg, Szwecja i Wielka Brytania (wykres 8). 


\section{Wykres 8}

Zależność między współczynnikiem przyrostu naturalnego a współczynnikiem obciążenia ludźmi młodymi w 27 krajach Unii Europejskiej w 2010 r.

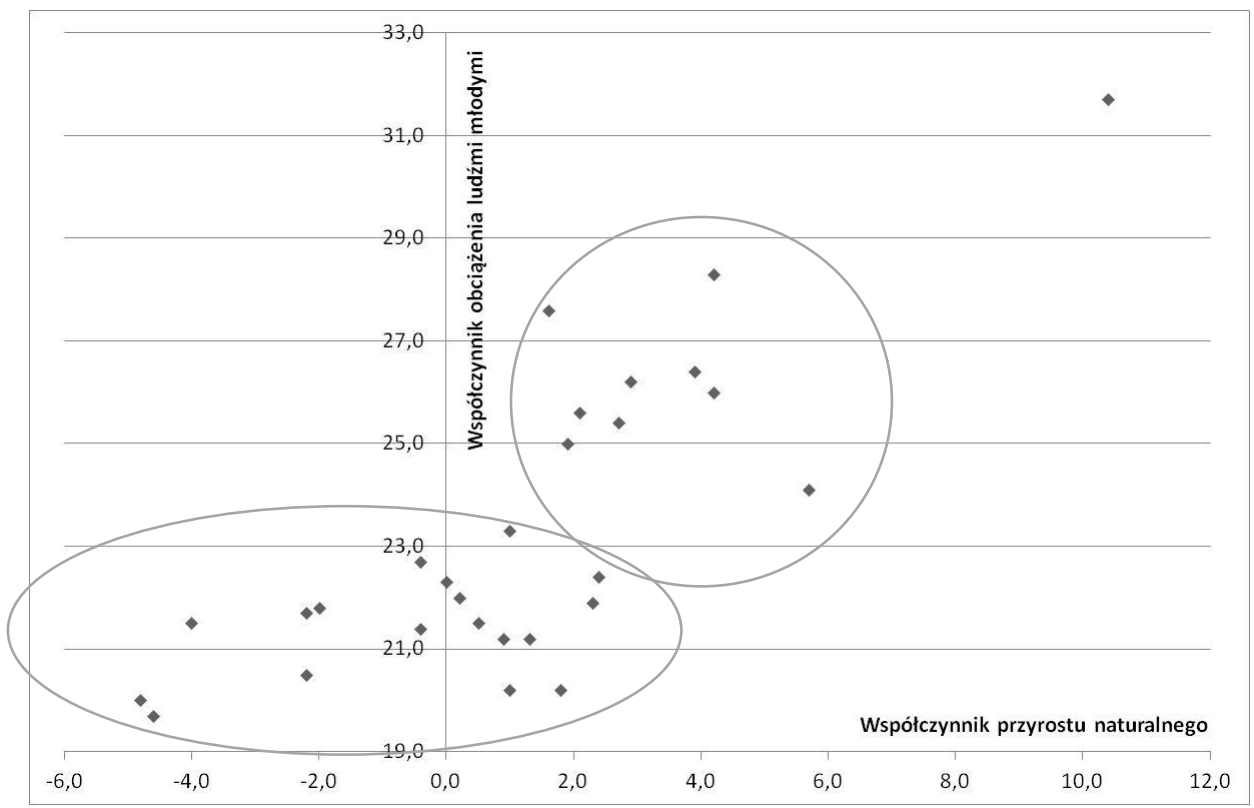

Źródło: opracowanie własne na podstawie danych bazy Eurostat, http://epp.eurostat.ec.europa.eu.

Pozostałe kraje Unii Europejskiej maja niskie lub wręcz ujemne wartości współczynnika przyrostu naturalnego oraz niskie obciążenie ludnością w wieku przedprodukcyjnym.

Analiza współwystępowania elementów ruchu naturalnego ludności i mierników obciążenia demograficznego w krajach Unii Europejskiej w 2010 r. wykazała, że bieżące zdarzenia ruchu naturalnego, przejawiające się w urodzeniach, zgonach oraz ich wzajemnej relacji, kształtują jedynie poziom obciążenia ludnością w wieku przedprodukcyjnym, natomiast ich wpływ na bieżące obciążenie ludnością w wieku poprodukcyjnym oraz na przeciętny wiek społeczeństwa jest niewielki lub wręcz nieistotny. Oznacza to, że relacja liczby ludności w wieku 65 lat i więcej do liczebności pozostałej części społeczeństwa może bardziej zależeć od długookresowych trendów w ruchu naturalnym niż od sytuacji bieżącej.

Kolejnym wnioskiem, jaki można wyciągnąć na podstawie braku wyraźnych zależności pomiędzy aktualnymi tendencjami w ruchu naturalnym ludności danego kraju a przeciętnym wiekiem społeczeństwa i obciążeniem demograficznym (szczególnie ludnością starszą), jest przypuszczenie, że w krajach o podobnych obecnie strukturach wieku ludności w przyszłości sytuacja demograficzna może kształtować się zupełnie odmiennie. Oznacza to, że choć 
problem starzenia się społeczeństwa istnieje w całej Unii Europejskiej, to każdy kraj powinien indywidualnie, zgodnie ze swoimi warunkami szukać drogi rozwiązania tego problemu i sposobów przeciwdziałania jego negatywnym skutkom, ewentualnie korzystając z doświadczeń innych krajów, ale dostosowując je do swojej sytuacji.

\section{OCENA SYTUACJI DEMOGRAFICZNEJ W KRAJACH UNII EUROPEJSKIEJ ZE WZGLĘDU NA NATĘŻENIA RUCHU NATURALNEGO ORAZ OBCIĄŻENIE DEMOGRAFICZNE}

$\mathrm{Na}$ podstawie natężenia elementów ruchu naturalnego ludności oraz wskaźników obciążenia demograficznego można opisać sytuację w krajach Unii Europejskiej z punktu widzenia zaawansowania procesu starzenia się społeczeństwa.

Najkorzystniejsza sytuacja demograficzna panuje w Ir la n di i i Lu k s e mburgu. W 2010 r. obciążenie ludności w wieku produkcyjnym ludnością w wieku 14 lat i mniej było wysokie i jednocześnie obciążenie ludnością w wieku powyżej 65 lat - niskie (w porównaniu z innymi krajami UE). Obecne wysokie natężenie urodzeń oraz niskie natężenie zgonów pozwala prognozować utrzymanie się tych korzystnych struktur demograficznych w przyszłości.

W 2010 r. pod względem obciążenia demograficznego dobra sytuacja wystąpiła również w Holandii (tzn. wysokie obciążenie ludźmi młodymi i niskie ludźmi starszymi). Przyrost naturalny w tym kraju w 2010 r. był dodatni, a jego natężenie było jednym $\mathrm{z}$ wyższych $\mathrm{w}$ Unii, jednak w głównej mierze za sprawa niskiego natężenia zgonów. Natężenie urodzeń w Holandii jest na poziomie nieznacznie wyższym od średniej dla Unii Europejskiej, co oznacza, że sytuacja demograficzna w przyszłości będzie również korzystna na tle innych krajów UE, choć w mniejszym stopniu.

Natomiast bieżące natężenie ruchu naturalnego jest optymistyczną przesłanką przyszłej sytuacji demograficznej we Francji i na Cyprze (wysokie natężenie urodzeń i niskie natężenie zgonów) oraz w Estonii, Belgii i Wielkiej Brytanii (wysokie natężenie urodzeń przy natężeniu zgonów na średnim poziomie). W krajach tych starzenie się społeczeństw będzie również postępować, jednak obciążenie demograficzne na tle innych krajów Unii będzie miało korzystną strukturę.

W takich krajach, jak: Łotwa, Węgry, a także A ustria, Por tugalia, obecna sytuacja demograficzna kształtuje się na przeciętnym w Unii Europejskiej poziomie. Jednak niekorzystne relacje $\mathrm{w}$ ruchu naturalnym, przejawiające się niskim natężeniem urodzeń, ujemnym lub bardzo niewielkim przyrostem naturalnym, pozwalają prognozować w przyszłości wzrost udziału osób starszych w ogólnej liczbie ludności, co spowoduje, że społeczeństwa te będą miały dużo wyższe współczynniki obciążenia ludnością w wieku poprodukcyjnym niż inne kraje UE. 
Problemom starzejącego się społeczeństwa, znacznym obciążeniu ludnością w wieku 65 lat i więcej oraz niewielkiemu udziałowi ludzi młodych już w $2010 \mathrm{r}$. musiały sprostać Grecja, Niemcy i Włochy. Sa to obecnie najstarsze społeczeństwa w Unii Europejskiej. Obserwacja mierników ruchu naturalnego w tych krajach pozwala przypuszczać, że sytuacja w tych państwach będzie się w przyszłości pogarszać, a wzrost udziału osób starszych w ogóle ludności będzie większy niż w innych społeczeństwach Unii Europejskiej. W tej sytuacji już od dłuższego czasu wymagane jest w tych krajach prowadzenie odpowiedniej polityki społecznej i ekonomicznej. Wydaje się, że z problemami starzejących się struktur demograficznych radzą sobie Niemcy, natomiast w Grecji i we Włoszech istnieje potrzeba poprawy przyjętych rozwiązań.

W pozostałych krajach zarówno obciążenie demograficzne, jak i natężenie ruchu naturalnego kształtuje się na przeciętnym dla Unii Europejskiej poziomie. Istnieje w nich problem rosnącego obciążenia demograficznego, a proces starzenia się społeczeństwa jest nieuchronny, lecz będzie on przebiegał na przeciętnym dla Unii zrównoważonym poziomie.

Sytuacja demograficzna w Pols c e charakteryzuje się niskim obciążeniem demograficznym i natężeniem ruchu naturalnego na średnim poziomie, podobnie jak w $\mathrm{C} z$ ech ach, na Słowenii i Słow a cji. Należymy do grupy krajów, w których proces starzenia się społeczeństwa nie przebiega tak gwałtownie i nie jest tak zaawansowany, jak w Niemczech, Grecji, we Włoszech, na Łotwie i na Węgrzech. Jednak nasza sytuacja jest dużo gorsza niż takich krajów, jak Francja, Irlandia czy Holandia.

\section{PODSUMOWANIE}

W krajach Unii Europejskiej udział osób starszych w ogólnej liczbie ludności będzie się zwiększał z powodu niekorzystnych tendencji dzietności zachodzących wraz z ciagłym wydłużaniem się życia. Projekcja demograficzna przeprowadzona przez Eurostat (oparta na danych dotyczacych populacji w dniu 1 stycznia 2010 r.) przewiduje, że do 2060 r. na każdą osobę w wieku 65 lat i więcej będą przypadać mniej niż dwie osoby w wieku 15-64 lat. Najbardziej znaczące zmiany spodziewane sa $\mathrm{w}$ latach 2015-2035, kiedy to generacje wywodzące się $\mathrm{z}$ powojennego wyżu demograficznego wejdą $\mathrm{w}$ wiek poprodukcyjny i przejdą na emeryturę ${ }^{1}$.

Starość jest często kojarzona $\mathrm{z}$ okresem w życiu zdominowanym przez przewlekłe choroby, niedołężność, niesamodzielność, jednak taki stan nie jest regułą. Osoby w podeszłym wieku, które pozostaja aktywne, moga mieć swój wkład w życie społeczne, na przykład poprzez pozostanie na rynku pracy oraz aktywne uczestnictwo $\mathrm{w}$ życiu rodzinnym i publicznym. W związku z tym stworzenie warunków osobom starszym, aby jak najdłużej pozostały aktywne

\footnotetext{
${ }^{1}$ Active Ageing and Solidarity between Generation - Statistical Portrait of the European Union 2012, European Commission, Publications Office of the European Union, Luxembourg 2011, s. 32.
} 
i samodzielne, oraz zapewnienie środków na opiekę socjalną i zdrowotną nad ludźmi w podeszłym wieku powinno być nadrzędnym celem polityki wobec problemu starzejącego się społeczeństwa.

Podobne wyzwania stoją przed rządami Polski, gdzie obecna sytuacja na tle innych państw europejskich przedstawia się bardzo korzystnie. Jednak, biorąc pod uwagę struktury wieku Polaków oraz tendencje, którym podlega model dzietności oraz przeciętne dalsze trwanie życia, obciążenie demograficzne ludźmi starszymi będzie wzrastać. Choć jesteśmy tego świadomi, to - biorąc pod uwage nasz system emerytalny, zdrowotny, redystrybucję dochodów państwa - nie jesteśmy na to przygotowani. Może więc warto pochylić się nad rozwiązaniami przyjętymi w innych krajach, które od dłuższego czasu borykaja się $\mathrm{z}$ problemem starzejącego się społeczeństwa i mimo to ich system społeczny funkcjonuje na bardzo dobrym poziomie (np. Niemcy, Francja, kraje skandynawskie) i rozwiązania te przystosować do warunków panujących w naszym kraju.

dr Matgorzata Szczyt

Uniwersytet Ekonomiczny w Poznaniu

NATURAL CHANGE IN POPULATION AND AGE DEPENDENCY

IN EUROPEAN UNION MEMBER STATES (A COMPARATIVE ANALYSIS)

Summary

The European Union's population structure is progressively becoming older. This process has been going on for the last thirty or forty years and is expected to continue for at least another half century.

The purpose of this paper is to present the relations between the statistics of natural change in population, and the demographic indicators of an ageing population: the median age and age dependency ratios. The analysis was based on the data from 2010 collected in twenty seven EU member states.

The analysis revealed that current events of natural change may affect only the young-age dependency ratio. The structure of the population aged 65 and over may depend more on the long-term trends in natural change than on the current situation.

The demographic situation in Poland is characterised by a low age dependency and average level of natural change. Poland belongs to a group of countries where the ageing process does not proceed so rapidly and is not as advanced as in Germany, Greece, Italy, Latvia and Hungary. Its situation is nevertheless much worse than that in, for example, France, Ireland or the Netherlands. 